\title{
Kortárs építészettörténet $V$. 100 éves a Bauhaus
}


Kortárs építészettörténet V.

100 éves a Bauhaus

Győr, 2019. október 25.

konferenciakötet, e-könyv

ISBN 978-615-0o-8383-4

DOI 10.46599/bauhaus.2020

A konferenciát szervezte:

Széchenyi István Egyetem

Építész-, Építő- és Közlekedésmérnöki Kar

Építészettörténeti és Városépítési Tanszék

https://eptorivaros.sze.hu/

A konferencia társszervezője és a kötet kiadója:

Győr-Moson-Sopron Megyei Építész Kamara

http://gyms.epiteszkamara.hu/

A konferencia együttműködő partnere:

ICOMOS Magyar Nemzeti Bizottság

http://www.icomos.hu/

A kötetet szerkesztette:

Veöreös András PhD és Horváth Tamás PhD

A borítón Koppány Attila festőművész, professor emeritus

Elmozdulás című akril, vászon képének részlete látható.

A kötet a „Nemzetköziesítés, oktatói, kutatói és hallgatói utánpótlás megteremtése, a tudás és technológiai transzfer fejlesztése, mint az intelligens szakosodás eszközei a Széchenyi István Egyetemen” című, EFOP-3.6.1-16-2016-ooo17 számú projekt támogatásával készült. 


\section{Tartalom}

Veöreös András PhD

Kortárs építészettörténet V. - 100 éves a Bauhaus - Beszámoló

Esther Bánki, Veöreös András

Ein mutiger Weg in schwierigen Zeiten - Das Leben der Bauhäuslerin Zsuzsanna Bánki

Egy bátor út a nehéz időkben - Bánki Zsuzsanna 'Bauhäuslerin' élete

Sebestyén Ágnes Anna

Miért nem stílus a Bauhaus?

Varga Piroska DLA

BauHaus QR kártya - Ma mi inspirál a Bauhausban?

M. Fábián Edit

Fehér vagy színes? A Bauhaus színhasználata

Hartmann Gergely

Korszakváltó épületek - A modern építészet kezdete és kibontakozása Győrött

Tárkányi Sándor DLA

Sopron két világháború közötti építészetének egyik legkiválóbb alkotója: Füredi Oszkár

Wettstein Domonkos PhD

Modernizáció és modern építészet a két világháború közötti

rekreációs célú építkezésekben

Karácsony Rita, Vukoszávlyev Zorán PhD

A magyar építészetoktatás reformja a II. világháború után -

A modernista szemlélet látszólagos háttérbe kerülése

Kuslits Tibor

A Bauhaus ködbevesző oldala - Egy jubileumi kirándulás hordalékai

Salacz Ádám, Vadász Balázs

Bauhaus pavilon 



\section{Modernizáció és modern építészet a két világháború közötti rekreációs célú építkezésekben}

\section{KIVONAT}

A fokozatosan kibontakozó modernitás a szabadidő és a rekreáció eltöltésének életformáiban is megfogalmazódott. A két világháború közötti időszakban, a Trianoni békét követően a történelmi fürdőhelyeitöl megfosztott Magyarországon mindez az új üdülőterületek kiépítésével esett egy időbe. A vidék kontextusában új funkciók és épülettípusok jelentek meg, ami a „korszerü” formálás számára is új lehetőségeket nyitott. Ugyanakkor a turisztika kezdettöl fogva különös érdeklödéssel fordult a vernakuláris kultúrához és előszeretettel alkalmazta a helyi formakincset és anyaghasználatot a rekreációs célú építkezésekben. A tanulmány célja a két világháború között kialakuló üdülőterületi építészet fogalmi kérdéseinek tisztázása a Balaton korabeli fejlesztési kérdéseinek modell értékü elemzésével. Elsősorban a korabeli szaksajtóban megjelent publikációkra támaszkodva járja körül, milyen értéktényezőkben jelentkezett a modernitás a Balaton-parti építkezésekben és hogyan értelmezhető a modern építészet hatása? A tanulmány rávilágít az új funkcionális szempontok alapján formálódó nyaraló építészet koncepcionális ellentmondásaira is.

A magyar modern építészetben hamar megjelentek a nyaralás modern felfogását hirdető hétvégi házak első példái, amelyek még ma is karakteresen képviselik a városból kivonuló ember szabadságvágyát és a természet közeli életformák keresését. Kozma Lajos Lupa-szigeti nyaralója 1935-ben készült el, ártéri helyzetéből adódóan vasbeton lábakon áll, invenciózus szerkezete felszabadult kísérletező formálást mutat. Ahogy Molnár Farkas 1934-es felsőgödi nyaralója is a maga egyszerüségével próbál közvetlen kapcsolatot teremteni a természeti környezettel. Mindkét alkotás korát megelőzve vetítette előre a modern nyaralóépítészet alapvető szerkesztési elve-

1 BME Urbanisztika Tanszék, wettstein.domonkos@gmail.com 
it. Bár a nehézkes villákat felváltó nyaraló építészet kifejezetten a modernitáshoz és a modern építészethez köthető, a korszakban csak kevés számú nyaralóépület épült ebben a szellemben Magyarországon. Érdemes megvizsgálnunk, hogyan hatott a kibontakozó modern építészet a Balaton-parti üdülöterületekre?

A modern építészet számára az üdülőterületek a felszabadult kísérletezés helyszíneit ígérték. Az európai üdülőhelyek frissen parcellázott üdülőtelkein a történeti előzmények hiányában a rekreáció életformájához alkalmazkodó épülettípusok tisztán artikulálhatták a modern építészet felfogását. A turisztikai érdeklődés ugyanakkor kezdettől fogva élénk érdeklődéssel fordult az üdülőtájak lokális, vernakuláris kultúrájához és előszeretettel alkalmazták a helyi formakincset a rekreációs célú építészetben. Épp ezért a modernitás absztrakt formálása és a vernakuláris építészet különös kapcsolata alakult ki az üdülöterületeken, ami ambivalens összképet eredményezett a frissen formálódó üdülőhelyek településképében.

A tanulmány célja a korabeli nyaralóépítészetet kísérő diskurzusok, fogalmi kérdések tisztázása. A témakör ma már a társtudományi kutatások fókuszában is megjelent, rávilágítva az üdülőterületeken megjelenő társadalmi rétegek életvitelére, önreprezentációs kérdéseire. A kutatások ugyanakkor kevésbé foglalkoznak az építészeti koncepcióalkotás problémájával. A tanulmány a szerző doktori disszertációjára is támaszkodik ${ }^{2}$, ugyanakkor a történeti rekonstrukcióhoz új fogalmi problémák felől közelít. Míg a Balaton-part építéstörténetét feldolgozó doktori kutatás a regionális szintủ koncepcióalkotás problémája felöl közelítette meg a korszakot, jelen tanulmány a modernitás perspektívájából elemzi a Balaton-parti fejlesztéseket és arra keresi a választ, milyen értéktényezőkben jelentkezett a modernitás a tópart frissen formálódó településképében?

\section{Urbánus és antiurbánus? \\ az üdülőterületi fejlesztések eszmetörténeti előzményei}

Az európai üdülöterületek kialakulására a huszadik század elején a korabeli plurális szemléletủ városépítészet különböző tendenciái hatottak. A nagyváros a hétköznapjaiból kiszakadni vágyó ember számára a turizmus a tájegységi desztinációkkal egy ellentett világ felfedezését ígérte. A nagyvárosi exodus inspirációjával kezdettől

2 A tanulmány kiindulópontjaihoz lásd a szerző korábbi kutatásait: Wettstein Domonkos: Regionális stratégiaalkotás a Balaton-part rekreációs célú építészetében (1928-1978). Doktori értekezés, BME Építészmérnöki Kar Csonka Pál Doktori Iskola, Budapest, 2018., illetve Wettstein Domonkos: Regionális törekvések a Balaton-parti üdülöterületek építéstörténetében a két világháború között. Építés- Építészettudomány 45 (2017) 1-2. 139-171. 
fogva jelen volt az üdülőterületek kialakításában egy antiurbánus karakter. A komfort és az infrastruktúra kiépítése ugyanakkor a táj és az üdülőterület szükségszerű urbanizációját is eredményezte. Az urbánus és antiurbánus tendenciák metszésében fogalmazódtak meg a különböző, sokszor ambivalens üdülőterületi stratégiák, amik a modern üdülőtájak kialakulását kezdettől fogva meghatározták. A korszak üdülőhelyeinek jellemzőit vizsgálva a Balaton-parti nyaraló építészet kialakulását modell értékünek tekinthetjük , a tóparti üdülőhelyek arculatában a rendelkezésre álló szükös források ellenére a korszak jellemző vonásait és problémáit fedezhetjük fel. Bár a korabeli fejlesztéseket nem kísérték érdemi elméleti diskurzusok, de a megvalósult példákban és publikált elképzelésekben az európai üdülőterületeket is átható eszmék tükröződtek.

De mit is jelentettek és hogyan érvényesültek ezek az urbanisztikai tendenciák? Meggyesi Tamás A városépítés útjai és tévútjai című munkájában, melyben a modern városépítészet gyökereit is feltárja, részletesen is elemzi ezeket a tendenciákat, ugyanakkor az üdülőterületek problémájával nem foglalkozik ${ }^{4}$. Érdemes tehát az üdülőterületek tükrében is áttekinteni a törekvéseket, hipotetikusan is rámutatva egy-egy hatásmechanizmusra, eszmetörténeti összefüggésre. Meggyesi a huszadik századi városépítészet forrásaiként a szociálutópiák és az urbánus hagyományok mellett a természet közelségét kereső alternatívaként az antiurbánus és a kertváros hagyományt említi. Az utóbbi kettőt érdemes részletesebben is elemezni, mert érdemben ezek a víziók jelentek meg az egyes üdülőtájak új településformáinak kialakításában. Az antiurbánus tendenciák esetében Meggyesi a villa motívumában látja a felfogás genezisét. Szerinte, ha a felvilágosodás gondolkodóját, Marc-Antoine Laugiert követve az építészet forrásának a természetet tekintjük, akkor „az erdő maga a város”. A városszéli kunyhót, mint az antirurbánus gondolkodás szimbólumát értelmezi és a villa antik értelmezésével, mint városideállal állítja párhuzamba. Elképzelését Hadrianus Villa Tivoli víziójával illusztrálja: „ez a hatalmas kertekben, teraszokban és vízfelületekben gazdag létesítmény a valóságos város antitézise, a szellemi és testi felüdülés szigete, ami méltán válhatott a humanista szellem és a pluralista polgári gondolkozás szimbólumává. A villa az erdőszéli kunyhó nagyszabású változa-

3 A korabeli balatoni fürdőtelepek kialakulásához lásd: Wettstein Domonkos: Regionális törekvések a Balaton-parti üdülőterületek építéstörténetében a két világháború között. Építés- Építészettudomány 45 (2017) 1-2. 139-171. illetve: Wettstein Domonkos: Fürdőtelepek és rekreációs célú együttesek rehabilitációja a Balaton-parton egy esettanulmány tükrében. In: A környezettudatos települések felé. III. Települési Környezet Konferencia. Szerk.: Fazekas István, Szabó Valéria, Meridián Alapítvány, Debrecen, 2012, 228-233.

4 Meggyesi Tamás: A városépítés útjai és tévútjai. Műszaki Kiadó, Budapest, 1985. p. 27. 


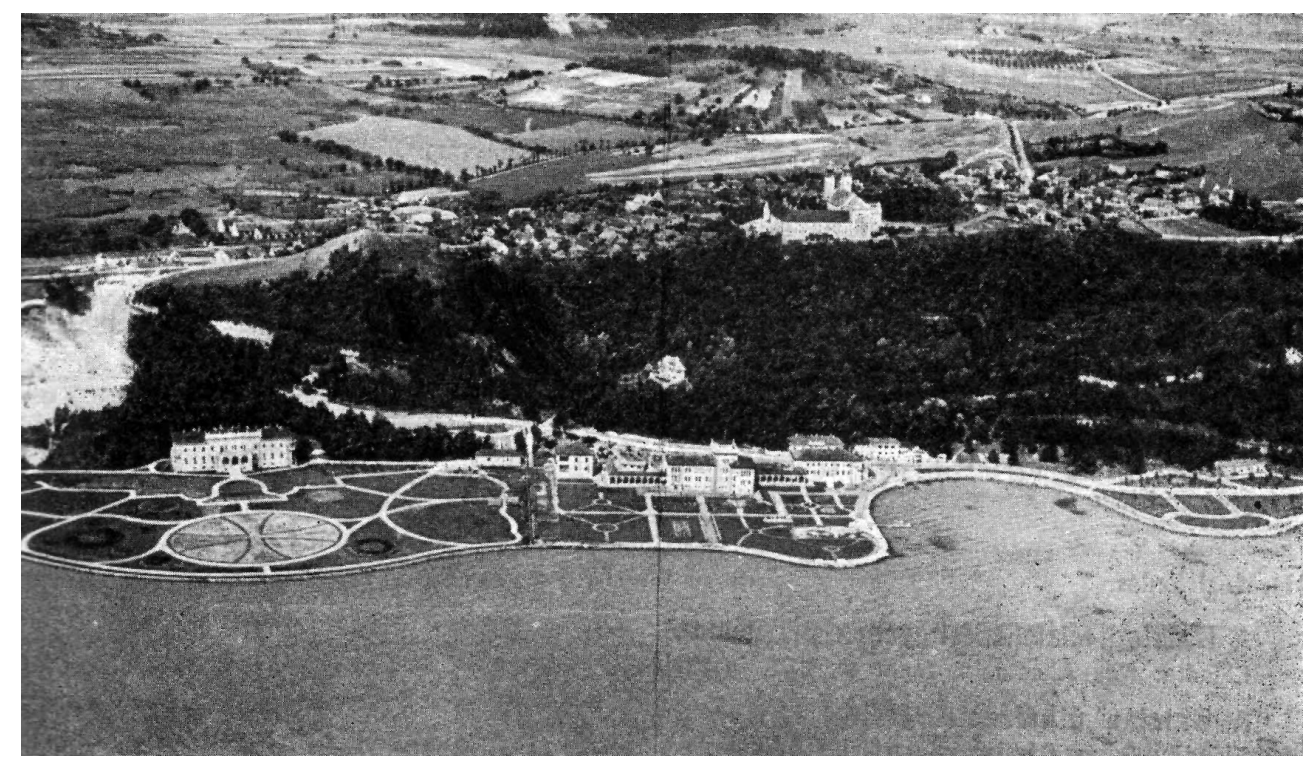

1. ábra: Tihany a harmincas évek elején. Forrás: Antal, 1931. p. 1.

ta.” Mindez tehát mutatja, hogy az antiurbánus gondolkodás forrásában a rekreáció gondolata kezdettől fogva jelen van. Az antiurbánus koncepciókat erősen inspirálta, hogy a turizmus számára a vidék plasztikusan, akár az építészet léptékében is tematizálható mintázatokat hordozott.

Az ellentett világot kereső eszmetörténeti tendencia a másik ága a vidék és a mezőgazdasági táj újraértelmezéséhez vezet vissza, ami a rekreáció koncepcionális érdeklődéséhez szintén közel áll. A vidék és a kultúrtáj minél közvetlenebb megtapasztalása a modern turisztikában is meghatározó motiváció. Az antiurbánus felfogásban Meggyesi szerint „a naturálgazdálkodás látszólag biztonságot nyújtó rurális világába” vágyakozás fogalmazódik meg. Az amerikai tájat hálós rendszerben átszövő ideális farmervárosok elképzelése előbb Thomas Jefferson, később Frank Lloyd Wright Broadacre City-jében jelent meg. Az amerikai és az európai tájakat behálózó vidéki településrendszerek a turizmus számára is bázist adhattak, ugyanakkor az életmódok átalakulásával és az infrastruktúra kiépülésével felerősödtek a táji urbanizációs folyamatok, ami a vidék turizmust inspiráló jellegzetességeinek elvesztéséhez vezetett. A táji urbanizáció, a rekreáció alapjait biztosító táji-természeti értékek elvesztése az üdülőhelyek egyik legnagyobb problémájává vált a huszadik századi fejlesztések eredményeképp.

5 Meggyesi, 1985. p. 28.

6 Meggyesi, 1985. p. 29. 
Az üdülőtelepek másik nagyhatású tervezési mintázatát a kertváros elképzelés adta (2, 3, 4. ábrák). Az eszme a természeti környezet jótékony hatásait és a közösségi élet, a városiasodás vívmányait kívánja szimbiotikusan összekapcsolni. Gyökere a 19. század második felének munkás telepeihez vezethető vissza, majd Ebenezer Howard dolgozta ki a kertváros programját. ${ }^{7}$ Elképzelését áthatotta a nagyvárosi exodus és a középkori kisváros iránt érzett nosztalgia, az Arts and Craft mozgalom ideológiája. A telepek megtervezésénél különös hangsúlyt helyezett a találkozások számára helyet adó központi parkot, valamint a lakónegyedektől jól elkülöníthető intézményi sávot. A kertváros idea számos telepszerü lakásépítés számára vált igazodási ponttá, ugyanúgy ahogy a korban megjelenő új parcellázású üdülőtelepek kialakítására is nagy hatással volt az eszme. A zöldövezetbe ágyazott korai olasz és francia tengerparti üdülőtelepek, mint a kertvárosok ideáljai jelentek meg a városi emberek számára, bár kétségtelen, ez az idea a valódi kertvárosok számára erősen illúzionisztikus volt, az üdülőtelepek elrendezésben csak az üdülés intézményeit és infrastruktúráját kellett elhelyezni, a hétköznapok intézményei a városokban maradtak. Magyarországon a nyugati tendenciák nem tudtak közvetlenül megvalósulni, csak a Wekerle telep kialakítása tükrözi a nemzetközi elképzeléseket. Az elméleti munkák közül Wildner Ödön, Boldizsár Miklós és Somogyi Miklós munkáiban jelent meg az elképzelés. ${ }^{8}$

Az antiurbánus tendenciák mellett az infrastruktúra fejlesztések révén modernizáció és a modernitás hatásai is plasztikusan kimutathatóak a század első felének üdülőtelepein. A modern városépítészet kialakulása erősen kapcsolódott a kertváros ideálhoz, az épített elemek és zöldfelületek kiegyensúlyozott komponálási viszonyához. Másrészről a modernitás a társadalom tömegessé válására és a tömeggyártásból fakadó új funkcionális és technológiai igényekre is válaszokat keresett, és ezeket a kérdéseket a turizmus tömegessé válása is provokálta. Az üdülőhelyi építkezések rohamosan növekvő számai hamar szükségessé tették az építészeti léptékű tipizálást, követhető minták kidolgozását a nyaralóépítészet terén is. A Modern Mozgalom és az 1933-as Athéni Charta városépítészeti elképzelése elsősorban a funkciók tiszta elkülönítésében érvényesült a korszakban frissen parcellázott üdülötelepek ideális kialakításában. A négy alapfunkcióból (lakás, munka, közlekedés, test és szellem ápolása) szükségszerűen kiemelkedik az utolsó, a rekreáció. Sőt a modern üdülőhelyek sokszor nem is a hozzájuk közvetlenül kapcsolódó vernakuláris táji, ősközségi

7 Ebenezer Howard: To-morrow: a Peaceful Path to Real Reform. London, 1898.

8 A kertvárosok korabeli magyar irodalmához Meggyesi, 1985 feldolgozása nyomán lásd: Wildner Ödön: A kertvárosok. in: Huszadik század, Budapest, 1906/1. Boldizsár Iván: Dánia, a gazdag parasztok országa. 2. kiadás. Franklin, Budapest, 1941. Somogyi Miklós: Kertmagyarország. 2. kiadás. Magyar Élet, Budapest, 1943. 

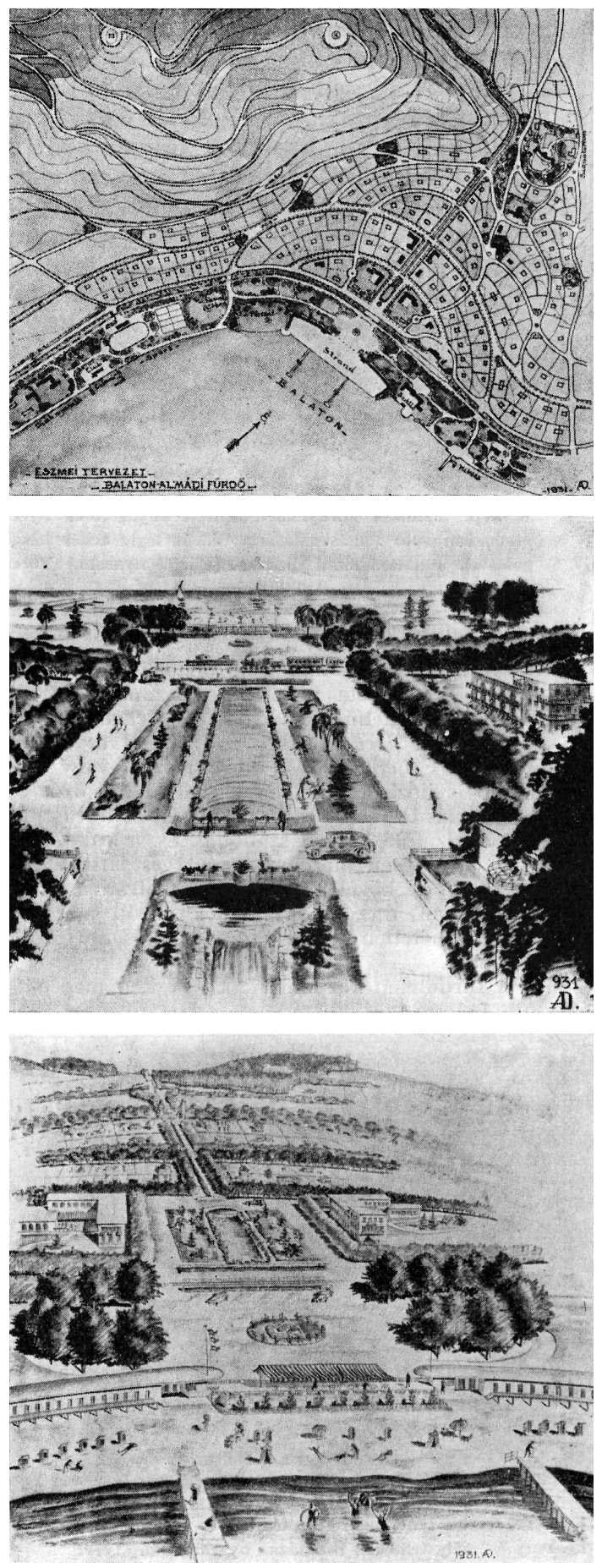

2, 3, 4. ábrák: Almádi rendezési elképzelése.

Forrás: Antal, 1931. pp. 37-38. háttérrel állnak szoros kapcsolatban, hanem a nagyváros kihelyezett territóriumaként viselkednek. Az üdülőhely tehát a modernitás négyes rendszerében a rekreáció zónája, amely mint ilyen a nagyváros szatelit szerűen kihelyezett eleme. Egy léptékváltással közelebb lépve természetesen az új modern telepítési elveket követő üdülőhelyeket is zónákra oszthatjuk, és ez a tiszta felosztás a szálláshelyek elkülönítése, a központi szórakozó helyek kiemelése céljából sok esetben valóban tisztán megvalósulhatott.

$\mathrm{Az}$ üdülőtájak rendezésében tehát az urbánus és antiurbánus koncepciók keveredtek, és ebben a vívódó kapcsolatban egyszerre volt jelen a nagyvárosi életvitel hátrahagyása és a természet közvetlen megtapasztalásának vágya éppúgy, mint a nagyvárosból magával hozott komfort és infrastruktúra igény. Az ellentmondások egyre inkább ambivalens összképet eredményeztek és az üdülőtájak torzulásához vezettek. Mindez az építészeti léptékben is megmutatkozott. Az üdülőhelyek reprezentatív arculatában eltérő felfogások és formálási stratégiák keveredtek. Egyszerre voltak jelen a turizmus romantikus és nosztalgikus érdeklődését kielégítő, a tájegységi építészetből inspirálódó alkotások és a modern rekreációs életformának keretet adó 
könnyed, kísérletező építészet. A nyaralás folyamatosan változó, nehézkes történeti formáit egyre inkább levetkőző életvitele új épülettípusokat és térformákat hívott életre. A villákat egyre inkább felváltó egyszerü, minimális térigényű nyaralók, az új komfortfokozatot biztosító hotelépületek, a vízi és hegyvidéki sportokhoz kapcsolódó klubépületek a kibontakozó modern építészet számára a felszabadult kísérletezés lehetőségét adták. Az 1937-es ötödik Párizsi kongresszusán a CIAM a lakás és a szabadidő eltöltésének problémáját helyezte a kongresszus fókuszába, és az ekkor már egyre szembetűnőbb üdülőterületi urbanizáció problémáját látva javaslatot tettek az üdülőtájak regionális léptékű rendezésére. ${ }^{9}$

\section{„Korszerű építészet” és stíluspluralizmus a Balaton-parton}

A modern mozgalom nemzetközi és hazai megszervezésével egy időben kezdődött el a Balaton-parti üdülőhelyek regionális szintű problémakörének rendezése. ${ }^{10}$ Érdemes megvizsgálnunk, hogy a két párhuzamos történeti folyamat, eseménysor kapcsolatba került-e egymással? Valamint, hogy a kibontakozó modern építészet számára milyen feladatok és lehetőségek nyíltak a Balaton-parton? A CIAM magyar csoportja informálisan már 1928-ban elkezdte hazai tevékenységét Molnár Farkas és Fischer József vezetésével. ${ }^{11}$ Ekkor indult el a Tér és Forma folyóirat Bierbauer Virgil és Komor János szerkesztésében. A lap szorosan kötődött a modern építészet hazai képviselőihez. A Balatoni Intéző Bizottságot 1929-ben alapította meg az állam a tópart ekkor már egyre inkább sürgető kérdéseinek egységes megoldására. A Magyar Mérnök- és Építész-Egylet 1931-ben szervezett értekezlet sorozatot a tópart építészeti kérdéseiről. Az esemény tanulságait és az előadások kivonatát a Tér és Forma folyóirat különszámban adta közre. Az építész szakma önszerveződéséhez kapcsolódik még az 1932-ben elindult „Hogyan építsünk” építési propaganda mozgalom², amelynek szintén volt Balatoni vonatkozása, a témában külön kiállítást szerveztek a tóparton. A modern mozgalomhoz kötődő építészeket azonban a vidék kérdésében nem a polgári középosztály nyaralási problémái, hanem a vidék szociális problémái foglalkoztatták. Elég csak az országtervezés jegyében a vidék strukturális újragondolására tett javaslatokra룰 vagy a dévaványai földművesház több léptéket összekapcsoló koncepciójára gondolnunk ${ }^{14}$. A tóparti üdülőhelyek rendezett településképének

9 Logis et Loisirs : 5ème congrès CIAM - Paris 1937. Ed. de l'architecture d'aujourd'hui, Paris, 1938.

10 Wettstein, 2017.

Ferkai András: Molnár Farkas, Terc, 2011. p. 378. 

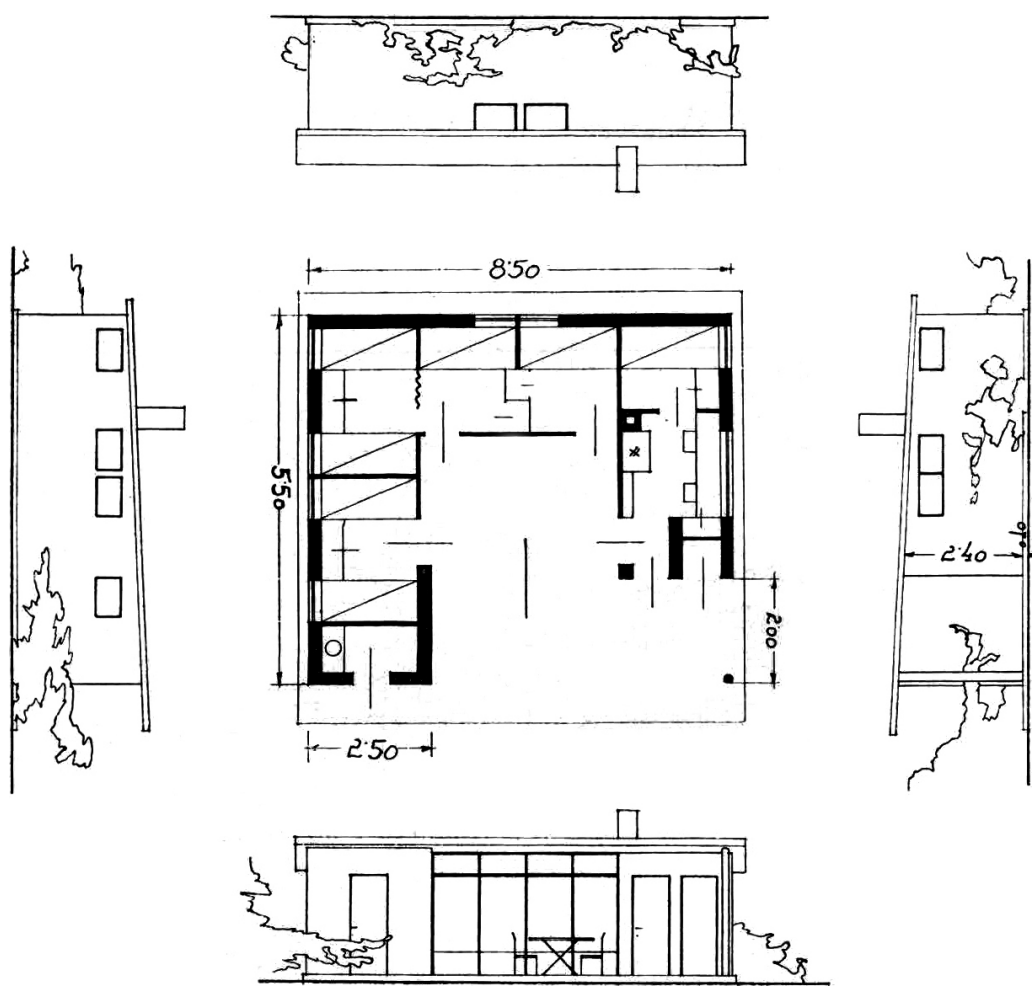

5. ábra: Korszerủ szemléletủ nyaralóépületek az MMÉE kiadványában:

Molnár Farkas terve. Forrás: Antal, 1931. p. 20.

ügyét Kotsis Iván karolta fel, aki személyesen is kötődött a tóparthoz. Az új üdülőhelyi építési feladatokra nem álltak rendelkezésre megfelelő minták, ezért a korszakot amúgy is jellemző stíluspluralizmus ${ }^{15}$ heterogén összképe még erősebben érvényesülhetett. Az üdülöterületi építészetben a turizmus számára különösen érdekesek voltak a nemzeti historizmus, a népi irányzatok ugyanúgy, mint a korszerű modern építészeti elvek. Mindez azonban a sok esetben tervezőként is megnyilvánuló helyi építőmesterek torzításában alakult tovább és a kvázi historizáló, népi vagy épp modern formák csak a maguk naiv formálásában realizálódtak.

A Magyar Mérnök- és Építész-Egylet 1931. február 9-16 között megtartott rendezvénysorozatán Kotsis Iván is a stíluspluralizmus problémáját emelte ki: „Nálunk még ma is a következő homlokzatok épülnek: 1. történeti stílusban (barokk vagy klasszikus stílusban); 2. magyaros stílusban és pedig a népies elemek különféle interpretálásával, 3. korszerü alakban, az illető építész felfogásához képest kevésbé vagy jobban

15 Ferkai András: Építészet a két világháború között. In: Sisa József, Dora Wiebenson (szerk.): Magyarország építészetének története. Vince Kiadó, 1998. pp. 275-304. 

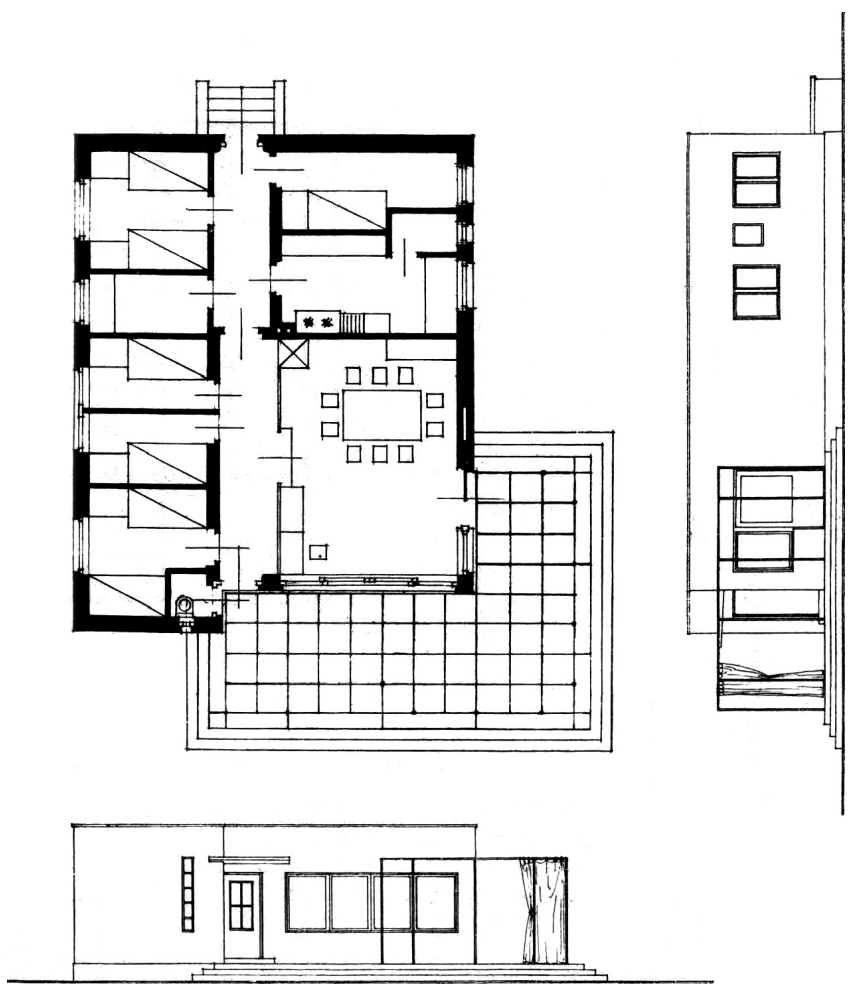

6. ábra: Korszerű szemléletű nyaralóépületek az MMÉE kiadványában: if. Masirevich György és Kaffka Péter terve. Forrás: Antal, 1931. p. 20.

haladó felfogásban.”6 Ez utóbbi utal a ma már átfogóan a „modern” eszmével jellemzett szemléletre, amit akkor még a „korszeru”” és a „haladó” fogalmával fedtek le. A „kevésbé vagy jobban” szintén mutatja a modern építészet kibontakozásának és érvényesülésének összetett hatásmechanizmusát. A széles spektrumra jó példa a cikkhez mellékelt „nyaraló példatár”, melyet a Kotsis felhívásához csatlakozó építészek készítettek el. A tervek közt vannak az archetipikus nyeregtetős házformát karakteres egyszerüséggel megjelenítő tervek, a Kotsis által széles körben népszerüsített alacsonyhajlású tetőformás épületek valamint a modern építészethez közelebb álló, szikár tömegkompozíciók. A tematikus lapszámban megjelenő terveket az építészek önkéntesen tették közzé a szerkesztők felhívására, több közülük egy korábbi megbízás sematizált átdolgozása. Ez az általános Balaton-parti, vagy sokkal inkább üdülőterületi jelleg mutatja a megoldások helytől, településtől független jellegét a modernizáció jegyében.

16 Kotsis Iván: Művészet a Balatoni építkezésekben. In: Antal Dezső (szerk.):

Balaton. A Tér és Forma kiadása, 1931. pp. 8-10. 
A nyaralótervezési elvekben a modernitás több vonása is megjelenik, ugyanakkor az épületek formai kialakítása már nem feltétlen köthető szorosan a modern építészet korabeli tendenciáihoz. A CIAM magyar csoportjának tagjai közül csak kevesen publikáltak a tematikus kiadványokban. A leginnovatívabb terv Molnár József vasvázas nyaraló terve, melyet a prototípusként a Siófokhoz közeli Balaton Lidóra készített el. A kvázi típustervként is felfogható konstrukció szemléletében korát megelőzte, a hozzá hasonló tipizált nyaraló tervek, vagy akár karosszéria jellegủ megoldások csak a hatvanas-hetvenes években jelentek meg. A háború előtti időszakban elsősorban mintatervekről beszélhetünk, amelyek inkább egyfajta elvrendszert, formai eszköztárat adtak az építőmesterek kezébe, akik aztán azt szabadon adaptálhatták a megrendelő kérésének és a helyi adottságoknak megfelelően. Molnár József földszintes és kétszintes megoldást is kidolgozott, az egyszerű térstruktúra a legszükségesebb térigényekre adott könnyed válaszokat. Vélhetően az alacsony komfort fokozat miatt sem terjedt el ez a megoldás a korszakban. Bár a gazdasági világválság szorításában kevés pénzből építkezett a középosztály, még a kisebb nyaralókat is összetettebb térstruktúrával építették meg. A korabeli irányelvekben javasolt hálókamrák, beépített búrotok még nem terjedtek el, ${ }^{17}$ csak a második világháborút követően, amikor már szélesebb néprétegek számára nyílik meg a Balaton-parti nyaralás lehetősége.

Molnár Farkas korai 1931-es balatoni nyaraló terve megjelent a Tér és Forma különszámában, a többi publikált példához hasonlóan helymegjelölés nélkül (5, 6. ábra) ${ }^{18}$. A vázlatos nyaralóterve egyszerủ földszintes négyzetes alapterületű tömeget mutat alacsony hajlású félnyeregtetővel fedve. A verandához kapcsolódó központi belső tér körül kvázi U alakban fordulnak körbe a kisebb helyiségek. Jellemző, hogy a praktikus, funkcionális elrendezés jegyében hálószobák helyett csak ágy méretủ hálókamrákat helyezett el a külső fal mellett. A belső tér szerkesztését a térbe állított pengeszerủ falak tagolják, bár ennek kidolgozottsága és szerepe a vázlatos rajz alapján nem egyértelmủ. Molnár Farkas életművében egy másik üdülőterületre, a fővároshoz közeli Felsőgödre tervezett nyaraló ismert megépült példaként 1934ből. ${ }^{19} \mathrm{Az}$ épület a modern, kisléptékü hétvégiház karakteres példája, az egyszerü tömegelemek játékos kompozíciója, a fedett nyitott terasszal kialakított plasztikus térformálás a hatvanas, hetvenes évek mintaterveinek is kedvelt eszközévé vált. A balatoni és a felsőgödi terv karakterében hasonlóak, koncepciójukban egyaránt a modern szerkesztési elvek dominálnak. A tematikus kiadványban ugyanakkor na-

Kaesz Gyula: Tanácsok nyaralók berendezéséhez. Magyar Építőművészet 43 (1944) 8. 199-200.

18 Antal, 1931. p. 20.

19 Ferkai 2011. p. 370. illetve Tér és Forma (1935) 1. pp. 22-23. 
gyobb számban jelennek meg az olyan alkotások, amelyek a „hely”, a táji adottságok témáját tömegformálásban, anyaghasználatban karakteresebben beépítik, ezzel a modern szerkesztési elveket is háttérbe szorítják. Molnár Farkas kései megépült alkotása a balatonszemesi dr. Czeyda-Pommersheim Ferenc részére tervezett villa, amely tömegformájával, a szegmensíves nyíláskialakításával és a kőburkolattal már nem mutatja a modern építészet elveit. ${ }^{20}$

\section{Tóparti modernitás: szállók és klubépületek}

A modernitás karakteres funkciói közé tartoznak a nagyobb kapacitású szállodák és az egyre népszerűbb sportélethez kapcsolódó klubházak. A kisebb panziókat felváltó nagyobb kapacitású és korszerü kialakítású hotelegységek is csak késve jelentek meg a Balaton-parton. Az első jelentősebb tóparti középítkezések közt már megjelentek az innovatív építészeti megoldások. Az ország első, nem ipari funkciójú vasbeton épületeként 1905-ben készült el a Balaton Club Balatonföldváron ifj. Ray Rezső és Zielinszky Szilárd tervei szerint. Az épület a környező szállodák vendégforgalmához kapcsolódott, eredetileg jacht klubnak és kaszinónak készült, a háború után a Hajtóműgyár Üdülőjeként építették át. Az épület tervezői a könnyed, vasbeton pillérvázzal és konzolos lemezszerkezetekkel, a premodern építészet kísérletező szemléletével korát megelőzve alakították ki a Balaton-part rekreációs célú építészetének karakterét. Ezt a karaktert keresi, bár a historizáló formákhoz még erősebben kötődik Bierbauer Virgil tihanyi sportszállója. A később a modern építészetben is meghatározó építész Mikle Károllyal közösen tervezte meg az épületet, amely 1923-ban készült el $^{21}$. A tóparti klubházak sorát később több játékos tömegformájú, a modern építészet könnyedségének inspirációját mutató épület készült el, elég csak a Tóth Kálmán által tervezett földvári Királyi Magyar Yacht Clubra, a balatonfüredi klubházakra vagy épp Wälder Gyula balatonszemesi vigadójára gondolnunk, melyet a helyi fürdőegyesület számára épített. Ez utóbbi jó példa, hogy a föként neobarokk stílusban tervező építész a tópart atmoszférájában már jóval könnyedebb, ugyanakkor szikárabb építészetben gondolkodott 1934-ben. Ezeknek a házaknak a tagozatoktól mentes letisztult homlokzatképzés és az azt ellenpontozó játékos tömegformálás egyaránt jellemzője. Valamint egyre meghatározóbbá vált az átmeneti terek gazdag struktúrája, az árnyékoló szerkezetek és a nagykiülésű ereszképzések alkalmazása.

20 Ferkai, 2011. p. 365.

21

Pesti Mónika: „... egy emberibb, őszintébb és racionálisabb építészetért...” 2018.03.06.

http://lechnerkozpont.hu/cikk/egy-emberibb-oszintebb-es-racionalisabb-epiteszetert (2019.12.30.) 
A fürdőtelepek klubházainak kiépülésével párhuzamosan ugyanakkor nem fejlődött a nagyobb kapacitású szálloda infrastruktúra. Már a század első évtizedeiben, mint a Balaton-part elmaradottságát demonstrálandó került napirendre az országgyűlésben a hotelférőhelyek alacsony száma. A szükséges fejlesztések ügyében a korabeli osztrák üdülőhelyeket hozták fel példaként, ahol ekkor már egyre több nagyobb szálloda üzemelt. A Balaton-parton ugyanakkor csak a harmincas évek második felében jelentek meg az első nagyobb épületkomplexumok. Ebben vélhetően a Balaton-parti turizmus szerkezete és jellege is szerepet játszott. Bár a külföldi vendégforgalom az utolsó békeévig folyamatosan emelkedett, nagyságrendje mégsem volt az európai üdülőhelyekhez fogható. A belföldi nyaralók számára pedig a saját hétvégiház építése volt a vonzó alternatíva. A Balaton építészeti kérdéseiről szervezett 1931-es ankéton Kiss Tibor tartott előadást a szállodaépítkezések helyzetéről.22 Előadásában kiemelte, hogy a tóparton csak harmad vagy első rangú szálloda található, a középosztály számára megfelelő „másodrangú polgári szállótípus” teljességgel hiányzik. Ehhez kapcsolódóan felvázolta a szerinte megfelelő kialakítást. A korszerü funkcionális követelményeknek megfelelően a gazdaságos középfolyosós elrendezést és a tóra merőleges kialakítást propagálta. Mindez végül csak a hatvanas évek szállodafejlesztéseinél terjedt el a tóparton, amikor Czigler Endre megtervezte a siófoki szállodasor épületeit. ${ }^{23}$ Kiss Tibor a hotelek kapcsán a széleskörű szemléletformálás lehetőségét is kifejezte: „... a nagylátogatottságú szállók igaz propagálói lehetnek egyben a valódi korszerú építészetnek is. Nevelő hatása van ezeknek az épületeknek, tehát építsük őket korszerúen, mert ne felejtsük el, az új korszerü müvészetet csak az tolja el magától, aki fél becsületesen ennek a problémának a szemébe nézni, és amíg nincsen alkalma annak előnyeit, igazságát gyakorlatban átélni. ${ }^{24}$ Fontos azonban hangsúlyoznunk, hogy Kiss Tibor, Kotsishoz hasonlóan a „korszerü” tágabb fogalmi keretet használja, és nem köti elképzelését a modern korabeli értelmezéséhez.

A hagyományos fürdőhelyeket, ahol már a 19. században kiépültek a jelentősebb szállodák, a Trianoni döntéssel elszakították. Az elzárt országban új tájegységekre irányult a figyelem, a szállodák elsősorban a szanatóriumi környezetet adó hegyvidékekben épültek. 1931-ben készült el a Kékes Szálló a Mátrában Miskolczy László tervei szerint, 1937-ben a Mecsek Szálló Lauber László tervei szerint, 1938-ban pedig a

22 Kiss Tibor: Balatoni szállodák. In: Antal, 1931. p. 32.

23 Siófok Aranypart, szállodasor 1962-1966. Lásd: „Balaton” szálló Siófok. 1962., Magyar Építőművészet (1963) 3 .

24 Antal, 1931. p. 32. 


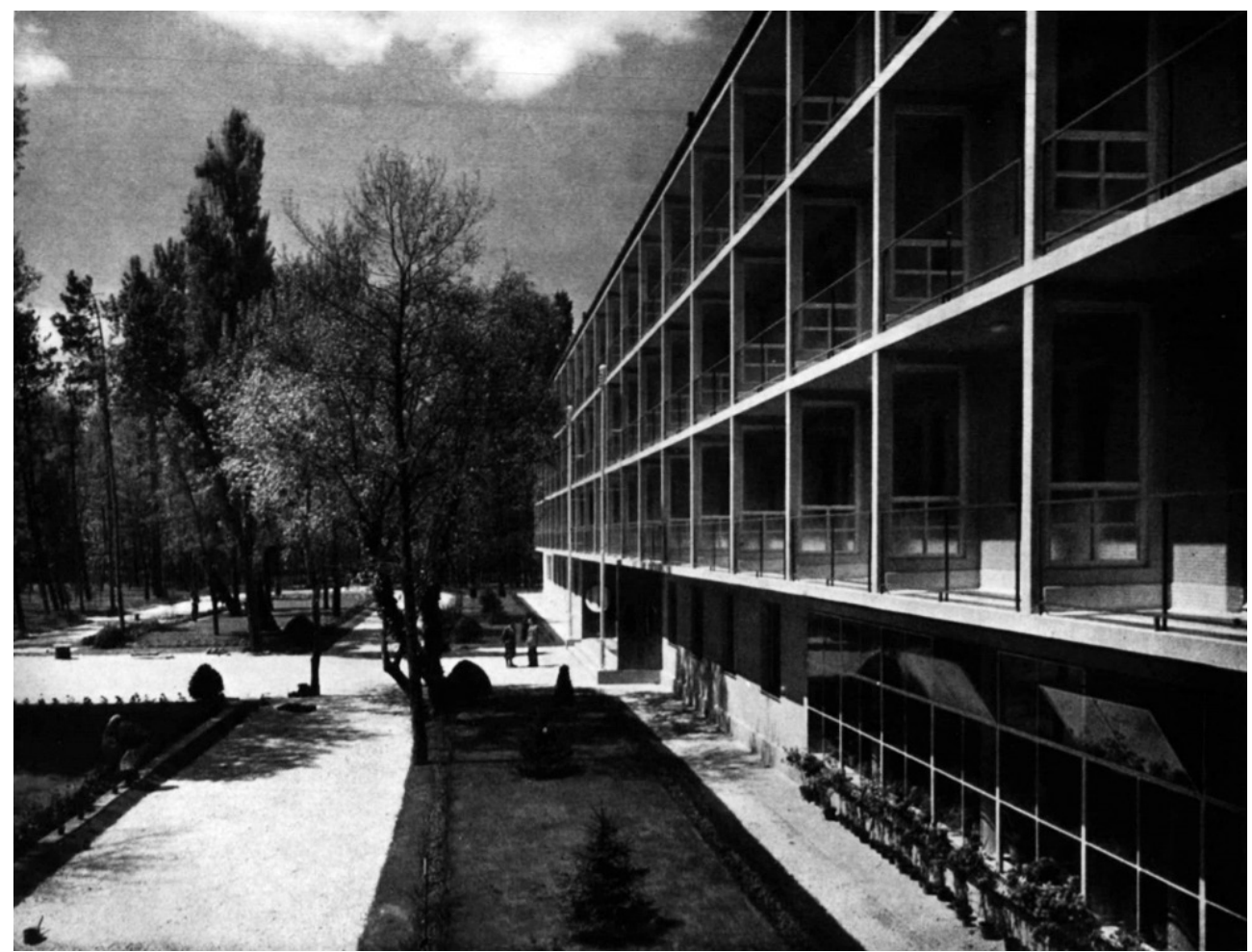

7. ábra: MABI üdülő, Balatonlelle. Forrás: Magyar Építőművészet (1944) 5. p. 126.

Gallyatető Nagyszálló Puskás Károly és Uray György munkájaként, melyet az Állami Alkalmazottak Nyugdíjjárulék Alapjából finanszíroztak. ${ }^{25}$ Budapesten a Sváb-hegyre és a Széchenyi-hegyre készültek kisebb szállodák. 1937-1941 között összesen nyolc szállodát építettek fel, 320 szobával, központi fútéssel. A modern szállodák közt megemlíthető még a Fischer József által jegyzett Rege és Gyopár, valamint Rákos Pál Új-Majestic szállója.

A Balaton-parton ebbe a hotelépítési hullámba illik a Hidasi Lajos által tervezett balatonlellei üdülőszálló, melyet a MABI alkalmazottak vehettek igénybe (7. ábra). Az épület 1938-ban készült el 150 férőhely kapacitással, 42 kétágyas, 12 háromágyas, 6 négyágyas szobával ${ }^{26}$. A déli parti sík területen két egymásra merőleges tömeget helyezett el a tervező, melyek köré fenyveses parkot rendezett. A szobákhoz a tóra néző oldalon erkélysor tartozik. A klimatikus szempontokra tekintettel a közösségi terek a tó felé nagy üvegfelületekkel nyílnak fel, amelyek a nyári melegben kinyithatóak.

25 Pamer, 2001.

26 Medvegy Elemér: Társadalompolitikai építkezések. Magyar Építőművészet (1944) 5. pp. 126-13o.

illetve Palmer, 2001. p. 188. 


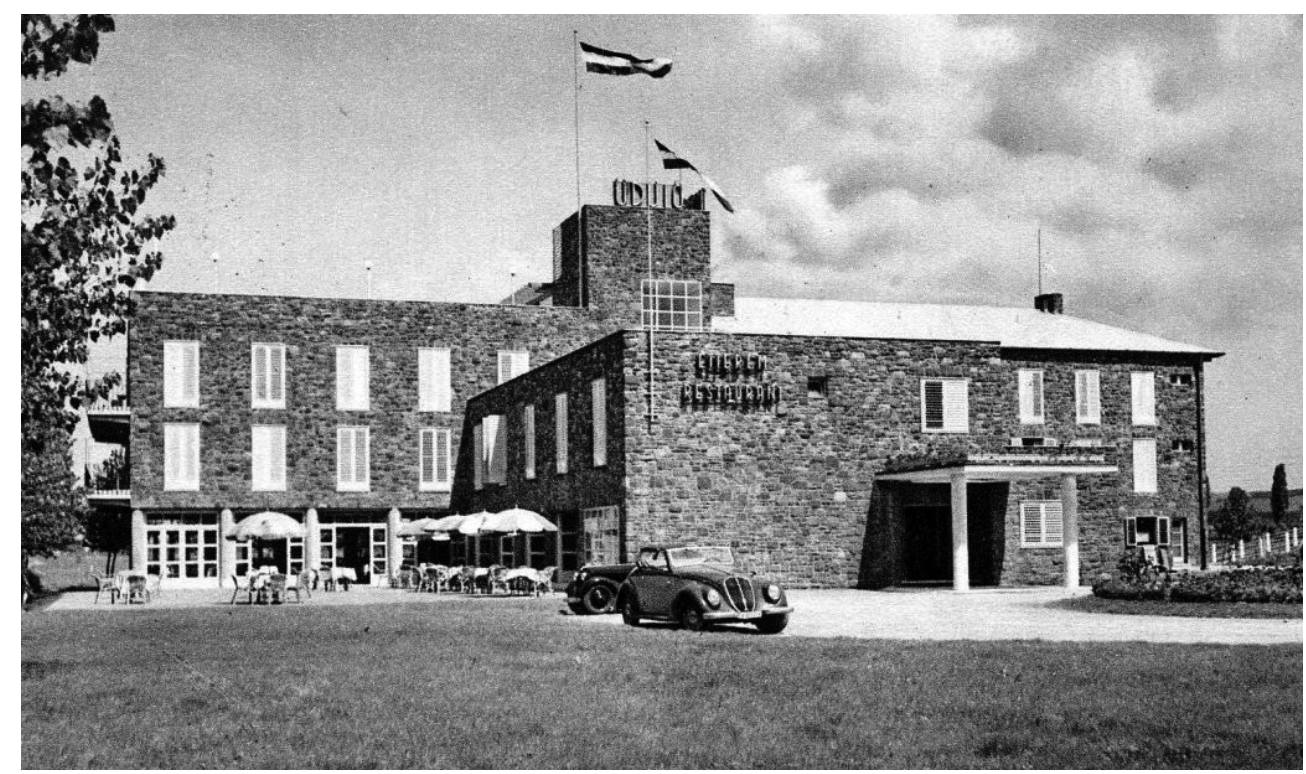

8. ábra: Balatonföldvár, üdülő. Forrás: archív képeslap

A korszak másik jelentősebb szállodaépülete Földváron épült (8. ábra). A Sellő Hotel építését Fenyő Zoltán szállodatulajdonos indította el még a harmincas évek elején, de pénzügyi és bünügyi problémák miatt az állam vette át, és fejezte be 1938-ban ${ }^{27}$. Bár az épületet a Pogány Móric (Töry és Pogány építésziroda) jegyzi, a terveket Janáky István készítette el 1936-ban ${ }^{28}$. Az épület a Janáky építészetét jellemző moderált modern formálást mutat. Az additív tömegformálást a homlokzatokat teljes egészében borító terméskő burkolat fogja össze. A szikár tömegeket a földszinti pillérváz és az erkélylemezek filigrán vasbeton szerkezetei ellenpontozzák. Az épület klasszicizáló karakterét a nyílásosztás arányai és ritmusa adja meg. Az épület ma már nem áll, a bauxitbeton szerkezetei miatt 1979-ben lebontották, helyére pártüdülő épült.

De milyen is lehetett volna egy, a polgári kultúrára épülő modern Balaton-part víziója? Erre egyetlen nagyobb terv készült a korszakban, a balatonaligai „Monte Carlo" projekt. Az aligai fürdőtelepet 1902-ben Tóth Ede balatonfökajári földbirtokos kezdte el kiépíteni. A telep léptékére jellemzö, hogy akkor 64 villatelket parcellázott, valamint fürdőkabinokat és vendéglőt telepített a partra. A telep életében léptékváltást jelentett, amikor 1943-ban a Monte Carlo nevű projekt keretében Olgyay Aladár és Viktor elkészítették a nemzetközi színvonalú és felszereltségủ hotelkomplexumból, sport és kulturális létesítményekből álló tervüket. A testvárpár 1910-ben született,

27 Internetes forrás: https://balatonfoldvar.info.hu/hu/villa/sello-szallo (utolsó belépés: 2019.12.30.)

28 Janáky István, Janáky György: Id. Janáky István könyve. Terc, Budapest, 2007. 


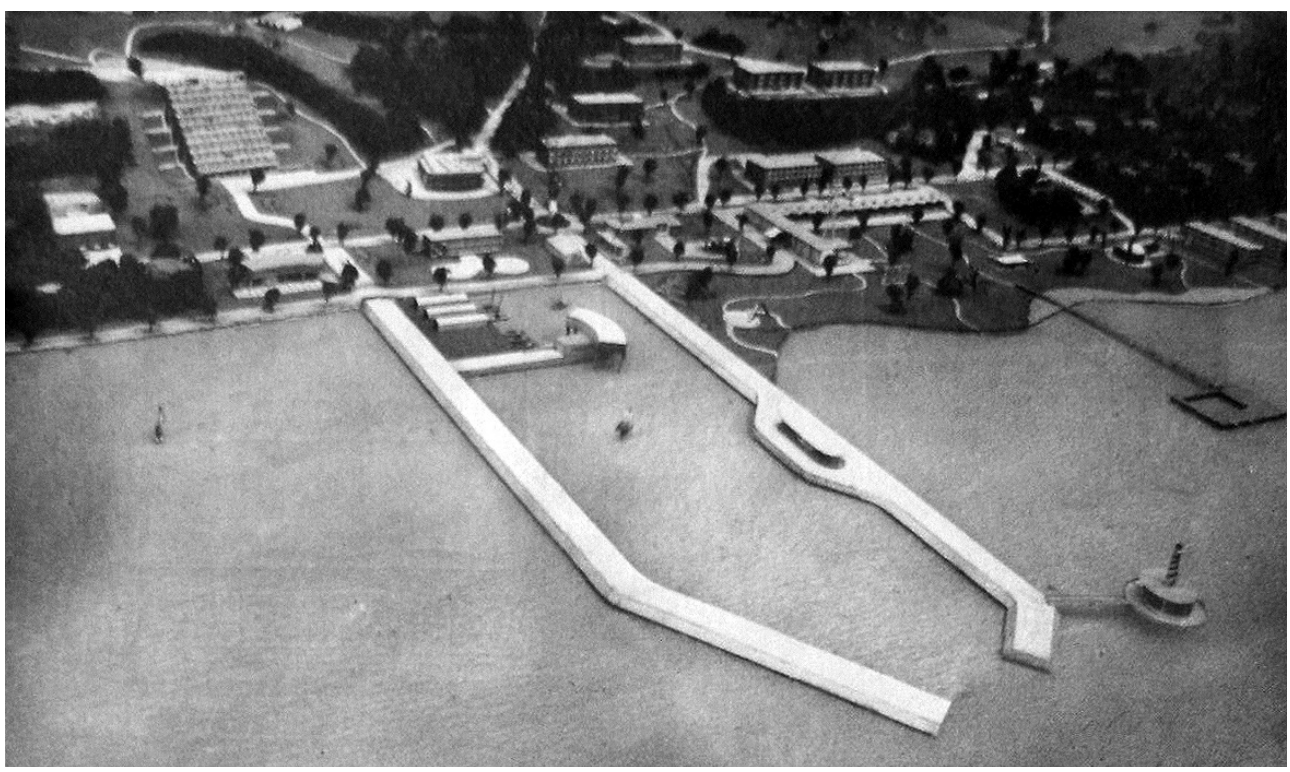

9. ábra: Az aligai fejlesztés modellje. Forrás: Magyar Építőművészet (1944) 8. p. 187.

1934-ben végeztek a Múegyetemen, majd nyugati tanulmányútjaik során nemzetközi tájékozottságra tettek szert. Párizsi és londoni tartózkodásuk során megismerkedtek a modern építészet meghatározó alakjaival, Le Corbusierrel, és Breuer Marcellel is. 1938-ban alapították meg közös irodájukat. ${ }^{29}$

Az aligai területet a modern szemlélet jegyében négy nagyobb területhasználati zónára osztották ${ }^{30}$. A topográfia karakterét követve kihasználták a meredek partfal, lejárat szerủ szurdok és a sík vízpart adta lehetőségeket ${ }^{31}$. (9. ábra) A projekt célja az üdülőközönség különböző rétegei számára alkalmas nyaralási formák kialakítása volt, amit a beépítés eltérő karakterei is kifejeztek. A nagyobb épületegységeket a tervezők igyekeztek a topográfiához illeszteni. Inspiráló volt számukra az akkor még „érintetlen” terepalakulatok formái, a házakat lépcsőzetesen alakították ki. A területre 3 nagyszállót terveztek 54 luxuslakással, szabadtéri színpaddal, teniszpályákkal, klubházakkal. A grandiózus elképzelésre és a modern tájformálás eszközeire jellemző, hogy a Balaton egy részét is fel akarták tölteni. A háborús évek alatt csak a Csongor és a Tünde nevű szállóegységek épültek meg. A modern szerkesztésmódot a

29 Munkásságukat lásd Olgyay \& Olgyay Építészek címmel a Művek és Művészek sorozatban, 1946.

30 Zsitva Tibor: Balatonaliga rendezési terve. Magyar Építőművészet 43 (1944) 8. pp. 185-193.

31 Kovács Zsófia: Olgyay \& Olgyay építészek - innovatív tervezési módszerek a ‘o-es években. in Karácsony Tamás (szerk.): Példázatok a megismerésről és továbbépítésről. Építész Mesterkurzus, BME Középülettervezési tanszék, Budapest, 2015. pp 180-189. 
tóra tájolt nagy üvegfelületek, a letisztult egyszerủ tartószerkezeti rendszer, a pillérek arányai és a részletképzés egyaránt mutatja. ${ }^{32} \mathrm{~A}$ táji környezethez való adaptációt a külső felületek terméskő burkolattal fogalmazták meg a tervezők. A házakat egyszerủ harántfalas struktúrával, a tófelé tájolt erkélyekkel alakították ki. Mindez az árnyékolásban is fontos szerepet játszott és előrevetíti a tervezők későbbi klimatikus építészet terén kifejtett gondolkodásmódját.33

A háborús frontvonal közeledtével a fejlesztés elakadt, a háborút követően az Olgyay fivérek Amerikába mentek, ahol 1947-től a Notre Dame Egyetemen, a Massachusets Technológiai Intézetben, majd a Princeton egyetemen elméleti kutatásaik keretében a klíma, épületenergetika, nap- és széljárás viszonyainak építészeti vonatkozásaival foglalkoztak34. Az aligai Monte Carlo-t Rákosi Mátyás 1948-ban államosította és itt alakíttatta ki pártüdülö 1. és 2. ütemét. Az épületegyüttes sorsa egyszerre mutatja a modern Balaton part víziójának történelmi kudarcát. A kétháború közt a tóparton fokozatosan elindult a polgári fejlődés, amit a civil szervezetek nagy száma és a tóparti kulturális élet gazdagsága egyaránt mutat. A nagyobb befektetők és turisztikai vállalkozások csak a korszak végére érkeztek meg, az új léptékủ és komfortfokozatú együttesek a nyugat-európai üdülöhelyek színvonalát követve már a modern építészet formanyelvével szerették volna kommunikálni a tóparti üdülés vízióját.

\section{Konklúzió}

Hogyan hatott a kibontakozó modern építészet a Balaton-parti üdülőterületekre? - A közlekedés fejlesztése, a szezonális szolgáltatások kiépítése révén a modernizáció és a modernitás kezdettől fogva összekapcsolódott az üdülőterületek kiépülésével. Az infrastruktúra elemei karakteres módon kezdték formálni a tájat, amelyet az üdülőtelepek modern, funkcionális elveken nyugvó zónás területhasználata tovább strukturált. Az építészeti formálásban ugyanakkor a tópart modernizációja már nem feltétlen párosult a modern építészeti formálással, ami a tópart két háború közti arculatában egyfajta ambivalens modernitást eredményezett. Mindez az üdülöterületek kialakulásának eszmetörténeti hatásmechanizmusából, az antiurbánus és

32 Hurták Gabriella: Egy elveszett világ. A Club Aliga építészeti emlékei.

In: Kerékgyártó Béla, Szabó Levente (szerkesztők): Építészet és idő. A 6o-as és 70-es évek magyarországi építészetének örökségéről. A BME Építőművészeti Doktori Iskola tanulmánykötete 2016-17,

BME Építőművészeti Doktori Iskola, Budapest, 2017. pp. 110-121.

Victor Olgyay: Design with Climate - bioclimatic approach to architectural regionalism,

Princeton University Press, New Jersey, 1963.

34 Jeffry Cook: Olgyay - Olgyay ikeriroda. Magyar Építőművészet (1987) 4-5. p. 14. 
kertváros felfogás érvényesüléséből is fakadt. Az urbánus keretek levedlésével a vidék mintázatainak tematizálása is megjelent az üdülőhelyek építészeti arculatában. Emellett a modern építészet visszafogott jelenlétében a korabeli építészcsoportok eltérő aktivitása és a tópart problémájához való hozzáállása is meghatározó szerepet játszott. A magyar építészet két világháború között aktív körei közül elsősorban nem a CIRPAC magyar csoportjához sorolt építészek, hanem személyes kötődéseik és társadalmi státuszuk révén a Kotsis Iván felfogásához kapcsolódó, szemléletükben a középosztály építészeti elképzeléseihez is közelebb álló építészek helyezték a Balaton-part problémáját a szakmai problémafelvetéseik homlokterébe. Mindezt az építészek Balatoni Intéző Bizottságban betöltött pozíciói is mutatják. Az építészeti minőség terén a törekvések egy sajátos regionális szintủ építészeti koncepció kialakulásához vezettek, amelyben a „korszerü” építészet hatásai is kimutathatóak, de elsősorban a helyi klimatikus, táji adottságokra és a középosztály üdülési életformájának sajátos térigényeire kerestek válaszokat. A modern építészet ellentmondásos érvényesülésének hátterében az építtetők társadalmi rétegét, az üdülésről alkotott elképzeléseiket és önreprezentációs szándékaikat, valamint a tóparton gyakorló tervező-kivitelezők képzetlenségét is feltételezhetjük, ezek részletesebb elemzése és kimutatása a jelen kutatásnak az egyes nyaralótelepek részletesebb vizsgálatára épülő további feladata.

\section{Források jegyzéke}

Antal Dezső (szerk.): Balaton. A Tér és Forma kiadása, 1931.

Czigler Endre: „Balaton” szálló Siófok. 1962., Magyar Építőművészet (1963) 3.

Ebenezer Howard: To-morrow: a Peaceful Path to Real Reform. London, 1898.

Ferkai András: Építészet a két világháború között. In: Sisa József, Dora Wiebenson (szerk.):

Magyarország építészetének története. Vince Kiadó, 1998. pp. 275-304.

Ferkai András: Molnár Farkas, Terc, 2011.

Gábor Eszter: A CIAM magyar csoportja (1928-1938), Akadémiai Kiadó, Budapest, 1972.

Hurták Gabriella: Egy elveszett világ. A Club Aliga építészeti emlékei.

In: Kerékgyártó Béla, Szabó Levente (szerkesztők) Építészet és idő. A 6o-as és 7o-es évek magyar-

országi építészetének örökségéről. A BME Építőművészeti Doktori Iskola tanulmánykötete 2016-17,

BME Építőművészeti Doktori Iskola, Budapest, 2017. pp. 110-121.

Internetes forrás: https://balatonfoldvar.info.hu/hu/villa/sello-szallo (utolsó belépés: 2019.12.30.)

Janáky István - Janáky György: Id. Janáky István könyve. Terc, Budapest, 2007.

Jeffry Cook: Olgyay - Olgyay ikeriroda. Magyar Építőművészet (1987) 4-5. p. 14.

Jürgen Joedicke: Modern építészettörténet (A forma, a funkció és a szerkezet szintézise)

Müszaki Kiadó, Budapest, 1961.

Kaesz Gyula: Tanácsok nyaralók berendezéséhez. Magyar Építőművészet 43 (1944) 8. pp. 199-200.

Kiss Tibor: Balatoni szállodák. In: Antal Dezső (szerk.): Balaton. A Tér és Forma kiadása, 1931. pp. 31-33.

Kotsis Iván: Mủvészet a Balatoni építkezésekben. In: Antal Dezső (szerk.): Balaton.

A Tér és Forma kiadása, Budapest, 1931. pp. 8-10. 
Kovács Zsófia: Olgyay \& Olgyay építészek - innovatív tervezési módszerek a ‘u-es években.

In Karácsony Tamás (szerk.): Példázatok a megismerésről és továbbépítésről. Építész Mesterkurzus, BME Középülettervezési Tanszék, Budapest, 2015. pp. 180-189.

Logis et Loisirs : 5ème congrès CIAM - Paris 1937. Ed. de l'architecture d'aujourd'hui, Paris, 1938.

Medvegy Elemér: Társadalompolitikai építkezések. Magyar Építőművészet (1944) 5. pp. 126-130.

Meggyesi Tamás: A városépítés útjai és tévútjai. Műszaki Kiadó, Budapest, 1985.

Pamer Nóra: Magyar építészet a két világháború között, Terc, Budapest, 2001.

Pesti Mónika: „... egy emberibb, őszintébb és racionálisabb építészetért...” 2018.03.06. Interentes forrás: http://lechnerkozpont.hu/cikk/egy-emberibb-oszintebb-es-racionalisabb-epiteszetert (utolsó belépés: 2019.12.30.)

Victor Olgyay: Design with Climate - bioclimatic approach to architectural regionalism,

Princeton University Press, New Jersey, 1963.

Wettstein Domonkos: Regionális stratégiaalkotás a Balaton-part rekreációs célú építészetében (19281978). Doktori értekezés, BME Építészmérnöki Kar Csonka Pál Doktori Iskola, Budapest, 2018.

Wettstein Domonkos: Regionális törekvések a Balaton-parti üdülőterületek építéstörténetében a két világháború között. Építés- Építészettudomány 45 (2017) 1-2. 139-171.

Wettstein Domonkos: Fürdőtelepek és rekreációs célú együttesek rehabilitációja a Balaton-parton egy esettanulmány tükrében. In: A környezettudatos települések felé. III. Települési Környezet Konferencia. Szerk.: Fazekas István, Szabó Valéria, Meridián Alapítvány, Debrecen, 2012, 228-233.

Zsitva Tibor: Balatonaliga rendezési terve. Magyar Építőművészet 43 (1944) 8. pp. 185-193.

\section{Képek forrásai}

1. ábra: Tihany a harmincas évek elején. Forrás: Antal Dezső (szerk.): Balaton.

A Tér és Forma kiadása, Budapest, 1931. p. 1.

2, 3, 4. ábra: Almádi rendezési elképzelése. Forrás: Antal, 1931. pp. 37-38.

5, 6. ábra: Korszerủ szemléletủ nyaralóépületek az MMÉE kiadványában: Molnár Farkas, valamint: iff. Masirevich György és Kaffka Péter tervei. Forrás: Antal Dezső (szerk.): Balaton.

A Tér és Forma kiadása, Budapest, 1931. p. 20.

7. ábra: MABI üdülő, Balatonlelle. Forrás: Medvegy Elemér: Társadalompolitikai építkezések.

Magyar Építőművészet (1944) 5. p. 126.

8. ábra: Balatonföldvár, üdülő forrás: archív képeslap. Online elérhető: https://balatonfoldvar.info.hu/ hu/foldvaron-es-kornyeken/sello-szallo\#\&gid=1\&pid=2 (utolsó belépés: 2019.12.30.)

9. ábra - Az aligai fejlesztés modellje. Forrás: Zsitva Tibor: Balatonaliga rendezési terve. Magyar Építőművészet 43 (1944) 8. p. 187. 